\title{
Hubungan Interaksi Sosial Dengan Perkembangan Moral Pada Remaja Di SMA UISU Medan
}

\author{
Anna Waty \\ Fakultas Psikologi \\ Universitas Medan Area
}

\begin{abstract}
Abstrak
Tujuan penelitian ini adalah untuk mengetahui hubungan snteraksi sosial dengan perkembangan moral pada pemaja di SMA UISU. Jenis penelitian yang digunakan dalam penelitian ini adalah kuantitatif. Populasi pada penelitian ini adalah siswa SMA UISU sebanyak 114 siswa/siswi yang terdiri dari kelas X (53 siswa), dan XI (61 siswa). Teknik pengambilan sampel yang digunakan adalah random sampling, Sampel yang digunakan diperoleh dari 50\% jumlah keseluruhan siswa dari masing-masing kelas, jadi sampel yang di dapatkan dari kelas X sebanyak 27 siswa, dari siswa kelas XI sebanyak 30 siswa. Teknik analisis data yang digunakan dalam penelitian ini adalah teknik analis korelasi Product Moment. Berdasarkan hasil analisis dengan Metode Analisis Korelasi Product Moment, diketahui bahwa terdapat hubungan positif yang signifikan antara Interaksi sosial dengan Perkembangan moral, dimana $\mathrm{r}_{\mathrm{xy}}=0,362 ; \mathrm{p}=0.001<0,005$. Artinya semakin Baik Interaksi sosial, maka semakin Baik Pekembangan moral. Koefisien determinan $\left(\mathrm{r}^{2}\right)$ dari hubungan antara variabel bebas $\mathrm{X}$ dengan variabel terikat $\mathrm{Y}$ adalah sebesar $\mathrm{r}^{2}=0,131$. Ini menunjukkan bahwa Perkembangan moral dibentuk oleh Interaksi sosial sebesar 13,1\%
\end{abstract}

Kata Kunci: Interaksi Sosial; Perkembangan Moral; Moral Remaja

\section{PENDAHULUAN}

Menurut Santrock (2003), moral lebih kuat mengenai tingkah laku yang dapat diterima dan tidak dapat diterima, tingkah laku etis, atau tidak etis, dan caracara dalam berinteraksi.

Seorang remaja akan mengalami perkembangan moral, seiring dengan semakin luasnya ia berinteraksi. Pada awalnya, seorang remaja hanya berinteraksi di lingkungan keluarganya. Di sini pembentukan dasar-dasar moral terjadi dan akan menjadi acuan bagi para remaja ketika ia berinteraksi (Santrock, 2003). Adapun yang dimaksud dengan perkembangan moral adalah perkembangan yang berkaitan dengan aturan mengenai apa yang seharusnya dilakukan oleh manusia dalam interaksinya dengan oran lain (Santrock dalam Desmita, 2005).

Pembentukan moral terasa sulit bagi remaja karena ketidak konsistenan dalam konsep benar dan salah yang ditemukannya dalam kehidupan seharihari yang membuat remaja bingung. Hal ini akan menjadi penghalang bagi remaja dalam proses pembentukan moralnya.

Banyak faktor yang membuat remaja menjadi tidak bermoral, seperti keluarga yang bersikap dingin dan tidak perduli satu sama lainnya, pengaruh teman sebaya yang berkelakuan buruk, kecanggihan teknologi yang disalah gunakan, hingga faktor lingkungan yang negatif. Penolakan sosial atau hukuman bagi perilaku yang salah, dari penerimaan sosial atau penghargaan bagi perilaku yang benar, anak memperoleh motivasi 
yang diperlukan untuk mengikuti standar perilaku yang ditetapkan anggota keluarga (Gunarsa, 1991). Faktor yang paling besar pengaruhnya terhadap moral emaja adalah lingkungan sosial anak remaja tersebut.

Maraknya kasus pelanggaran moral yang di alami oleh remaja yang diberitakan di berbagai media massa akhir-akhir ini sungguh sangat memperihatinkan. Masalah yang muncul di kalangan remaja bukan hanya dirasakan oleh kalangan remaja sendiri, tetapi juga oleh orang tua dan orang lain disekitarnya.

Fenomena yang terjadi di SMA UISU Medan, dapat digambarkan bahwa remaja moralnya tidak baik karena menurut pandangan orang tua, guru bimbingan konseling, itu sendiri. Adapun perilaku yang dapat dikategorikan tidak bermoral adalah sering melawan orang tua, membentak-bentak, berkata kasar, tidak perduli terhadap keluarga dan berbuat sesuka hatinya ketika dirumah. Menurut guru di sekolah, siswa sering melawan ketika mendapat hukuman, memaki, dan ketika belajar mereka sering menaikan kakinya dalam proses belajar mengajar di atas meja.

Lingkungan sering disebut patokan utama pembentukan perilaku. Semuanya dikaitkan dengan lingkungan dan manusia pun selalu tergantung pada lingkungannya dan manusia pasti akan selalu berinteraksi dengan lingkungannya.

Interaksi sosial menurut Shaw (dalam Ali, 2004) merupakan suatu pertukaran antara pribadi yang masingmasing orang menunjukkan perilakunya satu sama lain dalam kehadiran mereka dan masing-masing perilaku mempengaruhi satu sama lain. Seorang anak dapat membandingkan pemikiran dan pengetahuan yang telah dibentuknya dengan pemikiran dan pengetahuan orang lain.

Interaksi sosial seperti yang dikemukakan Bonner (dalam Gerungan, 2004) adalah suatu hubungan antara dua individu atau dimana kelakuan individu yang satu mempengaruhi, mengubah atau memperbaiki kelakuan individu yang lain atau sebaliknya.

Berdasarkan uraian di atas bahwa dalam perkembangan moral salah satu faktor yang mempengaruhinya ialah interaksi sosial.

\section{KAJIAN PUSTAKA}

\section{Remaja}

Masa remaja (adolescence) dimulai kira-kira antara usia 10-13 tahun dan berakhir kira-kira antara usia 18-22 tahun (Santrock, 2005). Menurut Hurlock (Sobur, 2005) masa remaja adalah masa transisi dari anak menuju dewasa, yaitu usia 11-21 tahun. 
Piaget (Hurlock, 1999) mengemukakan secara psikologis, masa remaja adalah usia individu berintegrasi dengan masyarakat dewasa, usia saat anak tidak merasa di bawah tingkat orangorang yang lebih tua melainkan berada dalam tingkat yang sama, sekurangkurangnya dalam masalah hak integrasi dalam masyarakat (dewasa) mempunyai aspek efektif, kurang lebih berhubungan dengan masa puber, termasuk juga perubahan intelektual yang mencolok.

Menurut Sarwono (2010) dalam proses penyesuain diri menuju kedewasaan, ada tiga tahap perkembangan remaja yaitu :

\section{a. Remaja awal}

Pada tahap ini, remaja masih terheran-heran akan perubahan-perubahan yang terjadi pada tubuhnya dan dorongandorongan yang menyertai perubahanperubahan itu, mengembangkan pikiranpikiran baru, cepat tertarik pada lawan jenis dan mudah terangsang secara erotis, ditambah dengan berkurang nya kendali terhadap "ego" menyebabkan para remaja awal ini sulit mengerti dan dimengerti oleh orang dewasa.

b. Remaja madya

Pada tahap ini, remaja sangat membutuhkan kawan-kawan ada kecenderungan narsistik yaitu mencintai dirinya sendiri, dengan cara lebih menyukai teman- teman yang mempunyai sifat-sifat yang sama dengan dirinya, remaja berada dalam kondisi kebingungan karena masih ragu harus memilih yang mana, peka atau peduli, ramai- ramai atau sendiri, optimis atau pesimis, dan sebagainya.

c. Remaja akhir.

Tahap ini adalah masa mendekati kedewasaan yang ditandai dengan pencapaian: 1) minat yang semakin mantap terhadap fungsi-fungsi intelektual. 2) egonya mencari kesempatan untuk bersatu dengan orang lain dan mendapatkan pengalaman-pengalaman baru; 3) terbentuknya identitas seksual yang tidak akan berubah lagi; 4) ego sentrisme (terlalu memusatkan perhatian pada diri sendiri) diganti dengan keseimbangan antara kepentingan diri sendiri dengan orang lain; 5) tumbuh dinding pemisah antara diri pribadi dengan masyarakat umum.

Menurut Ali (2005) ada beberapa perkembangan secara fisik dan psikis yang terjadi pada masa ini, seperti: a) perkembangan fisik; b) erkembangan kepribadian; c) perkembangan emosi; d) perkembangan interaksi social; e) perkembangan moral remaja

\section{Perkembangan Moral}

Perkembangan moral adalah perubahan penalaran, perasaan, dan 
perilaku tentang standar mengenai benar dan salah. Perkembangan moral memiliki dimensi intrapersonal, yang mengatur aktivitas seseorang ketika dia tidak terlibat dalam interaksi sosial dan dimensi interpersonal yang mengatur interaksi sosial dan penyelesaian konflik (Santrock, 2005). Lebih lanjut dikatakan bahwa ketika manusia dilahirkan, manusia tidak memiliki moral (immoral). Akan tetapi dalam dirinya terdapat potensi moral yang siap untuk dikembangkan. Melalui pengalamannya berinteraksi dengan orang lain (orangtua, saudara dan teman sebaya), anak belajar memahami tentang perilaku mana yang baik, yang boleh dikerjakan dan tingkah laku mana yang buruk yang tidak boleh dikerjakan.

Karakteristik perkembangan moral menurut (Wahyuning W, Jash, Rachmadiana M.H, 2003) yaitu: a) setia, jujur dan dapat dipercaya; b) baik hati, penyayang, empati, peka dan toleran; c) pekerja keras, bertanggung jawab dan memiliki disiplin diri; d) mandiri, mampu menghadapi tekanan kelompok; e) murah hati, memberi dan tidak mementingkan diri sendiri; f) memperhatikan dan memiliki penghargaan tentang otoritas yang sah, peraturan dan hukum; g) menghargai diri sendiri dan hak orang lain; h) menghargai kehidupan, kepemilikan alam, orang yang lebih tua dan orang tua; i) santun dan memiliki adab kesopanan; j) adil dalam pekerjaan dan permainan; k) murah hati dan pemaaf, mampu memahami bahwa balas dendam tidak ada gunanya; 1) selalu ingin melayani, memberikan sumbangan pada keluarga, masyarakat, negara, agama dan sekolah; m) pemberani; n) tenang, damai, dan tentram.

Aspek-aspek perkembangan moral menurut Piaget (dalam Santrock, 2005) adalah sebagai berikut: a) keinginan untuk bertanggung jawab; b) keinginan untuk mendapat keadilan; c) keinginan untuk menyelesaikan tugas.

Kohlberg (dalam Dariyo, 2004) menyatakan bahwa aspek-aspek yang terkandung dalam perkembangan moral adalah: a) orientasi patuh dan takut hukuman; b) orientasi naif egoistis (hedonisme instrumental); c) orientasi anak atau person yang baik; d) orientasi pelestarian otoritas dan aturan social; e) orientasi kontrol legalistis; f) orientasi yang mendasarkan atas prinsip dan kesadaran sendiri.

Menurut Piaget (dalam Hurlock, 1980) perkembangan moral mempunyai empat aspek, yakni: kematangan, pengalaman, transmisi sosial, ekulibrasi,

Berdasarkan uraian tersebut dapat disimpulkan bahwa aspek-aspek perkembangan moral terdiri atas: 
keinginan untuk bertanggung jawab, mendapat keadilan, mengikuti peraturan, menyelesaikan tugas, orientasi patuh dan takut hukuman, orientasi naif egoistis (hedonisme instrumental), orientasi anak atau person yang baik, orientasi pelestarian otoritas dan aturan sosial, orientasi kontrol legalistis, orientasi yang mendasarkan atas prinsip dan kesadaran sendiri, kematangan, pengalaman, transmisi sosial, dan ekuilibrasi.

Dari hasil penelitian, Kohlberg (dalam Desmita, 2005) mengemukakan enam tahap (stadium) perkembangan moral dilakukan dengan interval tiga tahun, dari masa remaja awal (10-16 tahun) sampai menginjak usia dewasa (2430 tahun) yang berlaku secara universal dan dalam urutan tertentu. Ada tiga tingkat perkembangan moral menurut kohlberg, yaitu tingkat 1) prakonvensional; 2) konvensional 3) pasca-konvensional. Masing-masing tingkatan moral tersebut terdiri dari dua tahap, sehingga keseluruhan ada enam tahapan yang berkembang secara bertingkat dengan urutan yang tetap. Tidak setiap orang dapat mencapai tahap terakhir perkembangan moral.

Menurut Piaget (dalam Desmita, 2005) moral bisa dibagi menjadi tiga jenis yaitu: moral individual, moral sosial, dan moral religi.
Menurut (Hurlock, 1999) ada empat faktor-faktor yang mempengaruhi perkembangan moral yaitu:

a. Mempelajari apa yang diharapkan kelompok sosial dari anggotanya sebagaimana dicantumkan dalam hukum, kebiasaan, dan peraturan

b. Mengembangkan hati nurani

c. Belajar mengalami perasaan bersalah dan rasa malu bila prilaku individu tidak sesuai dengan harapan kelompok

d. Mempunyai kesempatan untuk interaksi sosial untuk belajar apa saja yang diharapkan kelompok

Perkembangan nilai terjadi melalui identifikasi dengan orang-orang yang dianggapnya sebagai model. Pada usia 12 sampai 16 tahun, gambaran ideal yang di identifikasi adalah orang-orang dewasa yang berwibawa atau simpatik, orangorang terkenal, dan hal-hal ideal yang diciptakannya sendiri. Moral dan nilai menyatu dalam konsep superego, yang dibentuk melalui jalan internalisasi larangan-larangan atau perintah-perintah yang datang dari luar, khususnya dari orangtua (Desmita, 2005).

Sarwono (dalam Desmita, 2005) menyatakan bahwa hubungan anakorangtua bukanlah satu-satunya sarana pembentukan moral, karena masyarakat juga mempunyai peran penting dalam pembentukan kode moral. Tingkah laku 
yang terkendali disebabkan oleh adanya kontrol dari masyarakat itu sendiri yang mempunyai sanksi-sanksi tersendiri bagi yang melanggar. Jadi, dalam usaha membentuk perilaku sebagai pencerminan nilai-nilai hidup, jelaslah bahwa faktor lingkungan memegang peranan penting. Di antara segala unsur lingkungan sosial yang berpengaruh adalah manusiamanusia yang langsung dikenal oleh seseorang sebagai perwujudan dari nilai tertentu. Dalam hal ini lingkungan sosial terdekat adalah orang tua dan guru mereka.

Selanjutnya, Gunarsa (dalam Desmita, 2005) mengatakan bahwa teori perkembangan moral yang dikemukakan oleh Kohlberg menunjukkan bahwa sikap moral bukan hasil sosialisasi yang diperoleh dari kebiasaan dan hal-hal yang berhubungan dengan nilai kebudayaan melainkan terjadi dari aktivitas spontan pada masa kanak-kanak. Anak memang berkembang melalui interaksi sosial, tetapi interaksi ini mempunyai corak yang khusus dan faktor pribadi anak ikut berperan.

Berdasarkan uraian di atas dapat diambil kesimpulan bahwa faktor-faktor yang mempengaruhi perkembangan moral ialah mempelajari apa yang diharapkan kelompok, mengembangkan hati nurani, belajar mengalami perasaan bersalah dan rasa malu, mempunyai kesempatan untuk interaksi sosial, faktor lingkungan, faktor pribadi anak juga ikut berperan dalam pembentukan kode moral.

\section{Interaksi Sosial}

Menurut Herimanto (2008), Interaksi Sosial merupakan hubungan sosial yang dinamis, yang menyangkut hubungan timbal balik antar individu, antar kelompok manusia, maupun antara orang dengan kelompok manusia. Interaksi sosial menurut Sitorus (1995), merupakan suatu konsep abstrak yang dapat diterapkan pada kejadian-kejadian yang tak terbilang banyaknya dalam hidup sehari-hari. Dalam interaksi sosial, orang yang satu bertemu dengan yang lain entah secara tatap muka atau secara tidak langsung, entah untuk bekerja sama atau bersaing, dan seterusnya. Inti pokok dalam kehidupan sosial adalah interaksi, yaitu aksi atau tindakan yang dibalas dengan reaksi.

Menurut Homans (dalam Santosa, 1992), aspek-aspek interaksi sosial adalah sebagai berikut a) adanya motif atau tujuan yang sama; b) adanya suasana emosional yang sama; c) adanya hubungan; d) adanya internal dan eksternal sistem; e) adanya pimpinan. Sedangkan menurut Huky (2008) ada empat aspek penting dari interaksi sosial 
yaitu: komunikasi, norma kelompok, sikap (attitude), tingkah laku kelompok.

Berdasarkan uraian di atas dapat disimpulkan bahwa aspek yang mendasari terjadinya interaksi sosial adanya motif atau tujuan, suasana emosional yang sama, adanya hubungan, adanya eksternal dan internal sistem, adanya pimpinan, komunikasi, norma kelompok, sikap (attitude), dan tingkah laku kelompok.

Adapun bentuk-bentuk interaksi sosial yaitu kerja sama (cooperation), persaingan (competition), akomodasi (accommodation), dan pertentangan atau pertikaian (conflict). Keempat bentuk pokok interaksi itu dimulai dari kerja sama, kemudian menjadi persaingan, memuncak menjadi pertikaian, dan akhirnya sampai pada akomodasi (Santosa, 2004).

Faktor yang mempengaruhi interaksi social menurut Gerungan (2004) adalah: imitasi, sugesti, identifikasi, simpati.

\section{Hubungan Interaksi Sosial dengan Perkembangan Moral}

Perkembangan moral merupakan kebiasaan atau aturan yang harus dipatuhi oleh seseorang dalam berinteraksi dengan orang lain. Perkembangan moral memiliki dimensi intrapersonal, yang mengatur aktivitas seseorang ketika dia tidak terlibat dalam interaksi sosial dan dimensi interpersonal yang mengatur interaksi sosial dan penyelesaian konflik (Santrock, 2005). Sigmund Freud (dalam Santrock, 2005) mendasarkan bahwa karakter dan moralitas seseorang akan nampak lebih jelas lagi pada sat ia mulai bergaul dan bergaul dengan orang lain. Seiring dengan perkembangan sosial, anak juga mengalami perkembangan moral. Adapun yang dimaksud dengan perkembangan moral adalah perkembangan yang berkaitan dengan aturan mengenai apa yang seharusnya dilakukan oleh manusia dalam interaksinya dengan oran lain (Santrock dalam Desmita, 2005).

Gunarsa (1995) mengatakan bahwa seseorang dikatakan memperlihatkan adanya perkembangan moral, jika perilakunya sesuai dengan aturan-aturan yang ada dalam masyarakatnya, dengan kata lain perkembangan moral bersangkut paut dengan bertambahnya kemampuan menyesuaikan diri terhadap aturan-aturan atau kaidah-kaidah yang ada dalam lingkungan hidupnya atau dalam masyarakatnya dan diperlihatkan dalam perilaku yang terus-menerus atau bersifat tetap.

Interaksi sosial memegang peran penting dalam perkembangan moral pertama, dengan memberi anak standar perilaku yang disetujui kelompok sosialnya dan kedua dengan memberi mereka sumber motivasi untuk mengikuti 
standar tersebut melalui persetujuan dan ketidaksetujuan. Tanpa interaksi dengan orang lain anak tidak akan mengetahui perilaku yang disetujui secara sosial, maupun memiliki sumber motivasi yang mendorongnya untuk tidak berbuat sesuka hatinya. Interaksi sosial awal terjadi di dalam kelompok keluarga (Hurlock, 1999).

Anak belajar dari orangtua, saudara kandung, dan anggota keluarga lain apa yang dianggap benar dan salah oleh kelompok sosial tersebut. Penolakan sosial atau hukuman bagi perilaku yang salah, dan dari penerimaan sosial atau penghargaan bagi perilaku yang benar, anak memperoleh motivasi yang diperlukan untuk mengikuti standar perilaku yang ditetapkan anggota keluarga. Banyak faktor yang membuat remaja sekarang menjadi seorang individu yang kurang bermoral, seperti keluarga yang bersikap dingin dan tidak perduli satu sama lainnya, pengaruh teman sebaya yang berkelakuan buruk, kecanggihan teknologi yang disalah gunakan hingga faktor lingkungan yang negatif. Selain keluarga, faktor yang paling besar pengaruhnya terhadap moral remaja adalah lingkungan sosial anak remaja tersebut, Hurlock (1999).

Meninjau uraian di atas dapat disimpulkan bahwa perkembangan moral mempengaruhi interaksi sosial seperti Interaksi sosial memegang peran penting dalam perkembangan moral: pertama, dengan memberi anak standar perilaku yang disetujui kelompok sosialnya dan kedua dengan memberi mereka sumber motivasi untuk mengikuti standar tersebut melalui persetujuan dan ketidaksetujuan. Tanpa interaksi dengan orang lain anak tidak akan mengetahui perilaku yang disetujui secara sosial, maupun memiliki sumber motivasi yang mendorongnya untuk tidak berbuat sesuka hatinya.

\section{METODOLOGI PENELITIAN}

Jenis penelitian yang digunakan dalam penelitian ini adalah kuantitatif. Populasi pada penelitian ini adalah siswa SMA UISU sebanyak 114 siswa/siswi yang terdiri dari kelas $X$ (53 siswa), dan XI (61 siswa).

Teknik pengambilan sampel yang digunakan adalah random sampling, Sampel yang digunakan diperoleh dari $50 \%$ jumlah keseluruhan siswa dari masing-masing kelas, jadi sampel yang di dapatkan dari kelas $\mathrm{X}$ sebanyak 27 siswa, dari siswa kelas XI sebanyak 30 siswa.

Interaksi sosial dalam penelitian ini merupakan suatu proses hubungan sosial yang terjadi karena adanya hubungan timbal balik dan kerja sama yang baik dan adanya kontak langsung antara individu dengan individu, individu dengan 
kelompok dan kelompok dengan kelompok. Interaksi sosial diukur dengan menggunakan skala interaksi sosial yang disusun berdasarkan aspek-aspek yang dikemukakan (Huky, 2008) yaitu: komunikasi, norma kelompok sikap (attitude), dan tingkah laku kelompok, dengan asumsi semakin tinggi nilai yang diperoleh dari skala interaksi sosial berarti semakin baik pula interaksi sosial yang dimiliki individu dan sebaliknya semakin rendah nilai yang diperoleh dari skala interaksi sosial maka semakin buruk pula interaksi sosial individu tersebut.

Perkembangan moral dalam penelitian adalah kebiasaan atau aturan yang harus dipatuhi oleh seseorang dalam berinteraksi dengan orang lain. Perkembangan moral diukur dengan menggunakan skala perkembangan moral yang disusun berdasarkan aspek-aspek yang dikemukakan oleh Kohlberg (dalam Dariyo, 2004) yaitu: orientasi patuh dan takut hukuman, orientasi naif egoistis (hedonisme ininstrumental), orientasi anak atau person yang baik, orientasi pelestarian otoritas dan aturan sosial, orientasi kontrol legalistis, orientasi yang mendasarkan atas prinsip dan kesadaran sendiri dengan asumsi semakin tinggi nilai yang diperoleh dari skala perkembangan moral berarti semakin baik pula perkembangan moral yang dimiliki individu dan sebaliknya semakin rendah nilai yang diperoleh dari skala perkembangan moral maka semakin buruk pula perkembangan moral individu tersebut.

Data penelitian ini dibedakan atas data interaksi sosial dan data Perkembangan moral. Kedua data ini diperoleh dengan memberikan skala interaksi sosial dan skala perkembangan moral untuk diisi oleh subjek penelitian. Skala perkembangan moral disusun menggunakan skala Guttman, sedangkan skala interaksi sosial disusun dengan menggunakan skala Likert yang menggunakan 4 pilihan jawaban.

Skala Perkembangan Moral dalam penelitian ini disusun bedasarkan aspekaspek perkembangan moral yang dikemukakan menurut Kohlberg (dalam Dariyo, 2004) yaitu:

1. Orientasi patuh dan takut hukuman, merupakan suatu perilaku dinilai benar bila tidak dihukum dan salah bila perlu dihukum.

2. Orientasi naif egoistis (hedonisme instrumental), merupakan masih mendasarkan pada orang atau kejadian di luar diri individu, namun sudah memperhatikan alasan perbuatannya.

3. Orientasi anak atau person yang baik, merupakan anak menilai suatu 
perbuatan itu baik bila ia dapat menyenangkan orang lain.

4. Orientasi pelestarian otoritas dan aturan sosial, merupakan anak melihat aturan sosial yang ada sebagai sesuatu yang harus dijaga dan dilestarikan

5. Orientasi kontrol legalistis, merupakan memahami bahwa peraturan yang ada dalam masyarakat merupakan kontrol (perjanjian) antara diri orang dan masyarakat.

6. Orientasi yang mendasarkan atas prinsip dan kesadaran sendiri, merupakan peraturan dan norma adalah subjektif, begitu pula batasanbatasanya adalah subjektif dan tidak pasti.

Skala Interaksi Sosial dalam penelitian ini disusun berdasarkan aspekaspek interaksi sosial menurut (Huky, 2008) yaitu:

1. Komunikasi, merupakan proses pengiriman berita dari seseorang kepada orang lainnya.

2. Norma kelompok, merupakan nilainilai yang berlaku dalam suatu kelompok yang membatasi tingkah laku individu dalam kelompok itu.

3. Sikap (attitude), merupakan tindakan senang atau perasaan biasa-biasa saja dari seseorang.

4. Tingkah laku kelompok, merupakan dua orang atau lebih berkumpul di suatu tempat tertentu, mereka akan menampilkan perilaku yang sama sekali berbeda dari pada ciri-ciri tingkah laku individu-individu itu masing-masing.

Untuk uji validitas, teknik yang digunakan adalah analisis Product Moment dari Pearson dengan rumus sebagai berikut :

$$
r_{x y}=\frac{\sum X Y-\frac{\left(\sum X\right)\left(\sum Y\right)}{N}}{\sqrt{\left[\sum X^{2}-\frac{\left(\sum X\right)^{2}}{N}\right]\left[\sum Y^{2}-\frac{\left(\sum Y\right)^{2}}{N}\right]}}
$$

Uji reliabilitas dilakukan dengan alat ukur yang dipakai adalah teknik Hoyt dengan rumus:

$$
r_{t t}=1-\frac{M_{k t}}{M_{k s}}
$$

Metode analisa data yang digunakan dalam penelitian ini adalah teknik kolerasi product moment.

$$
r_{x y}=\frac{\sum X Y-\frac{\left(\sum X\right)\left(\sum Y\right)}{N}}{\sqrt{\sum X^{2}-\frac{\left(\sum X\right)^{2}}{N} \sum Y^{2}-\frac{\left(\sum Y\right)^{2}}{N}}}
$$

\section{HASIL DAN PEMBAHASAN}

Teknik analisis data yang digunakan dalam penelitian ini adalah teknik analis korelasi Product Moment. Namun, sebelum dianalisis dengan teknik analisis korelasi Product Moment, terlebih dahulu dilakukan uji asumsi terhadap variabel yang menjadi pusat perhatian, yaitu interaksi sosial sebagai data variabel bebas dan perkembangan moral sebagai variabel terikat yang meliputi uji 
normalitas sebaran, dan uji linearitas hubungan.

Berdasarkan uji coba diketahui skala interaksi sosial dari 42 aitem terdapat 36 aitem yang valid dengan skor bergerak dari $r b t=0,345$ sampai $r b t=0,841$. Sedangkan skala perkembangan moral dari 56 aitem terdapat 52 aitem yang valid dengan skor bergerak dari $r b t=0,341$ sampai $r b t=0,912$.

Uji normalitas sebaran dianalisis dengan menggunakan teknik KolmogorovSmirnov Goodness of Fit Test.

Tabel 1.

Rangkuman Hasil Perhitungan Uji Normalitas Sebaran

\begin{tabular}{|l|l|l|l|l|l|}
\hline Variabel & RERATA & SD & K-S & P & Keterangan \\
\hline $\begin{array}{l}\text { Variabel Perkembangan } \\
\text { moral }\end{array}$ & 44.035 & 11.209 & 1.321 & 0,056 & Normal \\
\hline Variabel Interaksi social & 117.772 & 14.702 & 0.929 & 0.354 & Normal \\
\hline
\end{tabular}

Keterangan :

$$
\begin{array}{ll}
\text { RERATA } & =\text { Nilai rata-rata } \\
\text { K-S } & =\text { Koefisien Kolmogorov-Smirnov } \\
\mathrm{SB} & =\text { Simpangan Baku } \\
\mathrm{p} & =\text { Peluang Terjadinya Kesalahan }
\end{array}
$$

Berdasarkan uji lineritas, dapat diketahui apakah variabel bebas dan variabel tergantung dapat atau tidak dapat dianalisis secara korelasional. Hasil analisis menunjukkan bahwa variabel terikat (perkembangan moral) mempunyai hubungan yang linearitas terhadap variabel bebas (interaksi sosial).

Sebagai kriterianya, apabila $\mathrm{p}$ beda < 0.05 maka dinyatakan mempunyai derajat hubungan yang linear (Sugiyono, 2011). Hubungan tersebut dapat dilihat pada tabel berikut ini :
Tabel 2.

Rangkuman Hasil Uji Linearitas Hubungan

\begin{tabular}{|l|l|l|l|}
\hline KORELASIONAL & F Beda & p Beda & KETERANGAN \\
\hline $\mathrm{X}-\mathrm{Y}$ & 8.276 & 0.006 & Linier \\
\hline
\end{tabular}

Keterangan :

$\mathrm{X}=$ Interaksi sosial

$\mathrm{Y} \quad=$ Perkembangan moral

F BEDA $=$ Koefisien linieritas

$\mathrm{p} \mathrm{BEDA}=$ Proporsi peluang ralat

\section{Hasil Perhitungan Analisis Data}

Berdasarkan hasil analisis dengan Metode Analisis Korelasi Product Moment, diketahui bahwa terdapat hubungan positif yang signifikan antara Interaksi sosial dengan Perkembangan moral, dimana $r_{x y}=0,362 ; p=0.001<$ 0,005. Artinya semakin Baik Interaksi sosial, maka semakin Baik Pekembangan moral.

Koefisien determinan $\left(\mathrm{r}^{2}\right)$ dari hubungan antara variabel bebas $\mathrm{X}$ dengan variabel terikat $\mathrm{Y}$ adalah sebesar $\mathrm{r}^{2}=$ 0,131. Ini menunjukkan bahwa Perkembangan moral dibentuk oleh Interaksi sosial sebesar $13,1 \%$. Tabel di bawah ini merupakan rangkuman hasil perhitungan r product moment.

Tabel 3.

Rangkuman Perhitungan Analisis Korelasi Product Moment

\begin{tabular}{|l|l|l|l|l|l|}
\hline Statistik & Koefisien $\left(\mathrm{r}_{\mathrm{xy}}\right)$ & Koef. Det. $\left(\mathrm{r}^{2}\right)$ & $\mathrm{P}$ & $\mathrm{BE} \%$ & Ket \\
\hline $\mathrm{X}-\mathrm{Y}$ & 0.362 & 0.131 & 0.003 & 13.1 & $\mathrm{~S}$ \\
\hline
\end{tabular}

Keterangan :

$\mathrm{X}=$ Interaksi Sosial

$\mathrm{Y} \quad=$ Perkembangan Moral

$\mathrm{r}_{\mathrm{xy}} \quad=$ Koefisien hubungan antara $\mathrm{X}$ dengan $\mathrm{Y}$

$\mathrm{R}^{2} \quad=$ Koefisien determinan $\mathrm{X}$ terhadap $\mathrm{Y}$

$\mathrm{p}=$ Peluang terjadinya kesalahan

$\mathrm{BE} \%=$ Bobot sumbangan efektif $\mathrm{X}$ terhadap $\mathrm{Y}$ dalam persen

Ket $=$ Sangat signifikan pada taraf signifikansi $5 \%$ atau $\mathrm{p}<0,010$. 
Tabel 4

Hasil Perhitungan Nilai Rata-rata Hipotetik dan Empirik

\begin{tabular}{|l|l|l|l|l|}
\hline \multirow{2}{*}{ Variabel } & \multirow{2}{*}{ SB / SD } & \multicolumn{2}{|l|}{ Nilai Rata-Rata } & \multirow{2}{*}{ Keterangan } \\
\cline { 3 - 4 } & & Hipotetik & Empirik & \\
\hline Perkembangan moral & 11.209 & 26.00 & 44.035 & Baik \\
\hline Interaksi sosial & 14.702 & 90.00 & 117.772 & Tinggi \\
\hline
\end{tabular}

Pembahasan

Berdasarkan analisis Product

Moment diperoleh hasil bahwa terdapat hubungan positif yang signifikan antara interaksi sosial dengan perkembangan moral pada remaja di SMA UISU Medan dengan koefisien korelasi $r_{x y}=0,362$ berarti $\mathrm{p}=0.000<0,050$, yang artinya semakin baik interaksi sosial maka semakin baik perkembangan moral remaja, sebaliknya semakin buruk interaksi sosial maka semakin buruk perkembangan moral remaja.

Dari penelitian ini membuktikan bahwa interaksi sosial memiliki andil yang cukup berarti dalam menentukan perkembangan moral remaja. Interaksi Sosial memberi pengaruh sebesar 13,1\% terhadap Perkembangan Moral. Masih terdapat $86,9 \%$ pengaruh dari faktor lain, dimana faktor tersebut dalam penelitian ini tidak dilihat. Hasil penelitian ini sejalan dengan pendapat Hurlock (1999) yang menyatakan bahwa salah satu satu faktor perkembangan moral yaitu interaksi sosial. Interaksi sosial memegang peran penting dalam perkembangan moral pertama, dengan memberi anak standar perilaku yang disetujui kelompok sosialnya dan kedua dengan memberi mereka sumber motivasi untuk mengikuti standar tersebut melalui persetujuan dan ketidaksetujuan. Tanpa interaksi dengan orang lain anak tidak akan mengetahui perilaku yang disetujui secara sosial, maupun memiliki sumber motivasi yang mendorongnya untuk tidak berbuat sesuka hatinya. Interaksi sosial awal terjadi di dalam kelompok keluarga.

Santrock (2003) Pada awalnya, seorang remaja hanya berinteraksi di lingkungan keluarganya. Sigmund Freud (dalam Santrock, 2005) mendasarkan bahwa karakter dan moralitas seseorang akan nampak lebih jelas lagi pada sat ia mulai bergaul dan bergaul dengan orang lain. Saat remaja keluar dari lingkungan keluarganya, maka lingkungan tempat tinggal tersebut yang menjadi tempat bersosialisasi. Karakter lingkungan tempat tinggal merupakan faktor terpenting setelah keluarga dalam pembentukan pribadi, perilaku, dan moral remaja. Perkembangan moral memiliki dimensi intrapersonal, yang mengatur aktivitas seseorang ketika dia tidak terlibat dalam interaksi sosial dan dimensi interpersonal yang mengatur interaksi sosial dan penyelesaian konflik . Interaksi ini akan menjadi pembelajaran bagi remaja dalam menentukan moral yang akan dibentuk (Santrock, 2005). 
Hasil yang diperoleh dari penelitian ini diketahui bahwa subjek penelitian ini yakni SMA UISU Medan memiliki interaksi sosial dengan perkembangan moral yang baik. Sebab pada interaksi sosial dapat dilihat nilai empirik sebesar 117.772 lebih besar dari pada nilai ratarata hipotetiknya, yakni 90. Demikian pula halnya dengan perkembangan moral, nilai empirik 44.035 lebih kecil dari pada nilai rata-rata hipotetiknya yakni 26.

\section{PENUTUP}

\section{Simpulan}

Berdasarkan hasil-hasil yang telah diperoleh dan melalui pembahasan yang telah dibuat, maka dapat disimpulkan bahwa terdapat hubungan positif yang signifikan antara interaksi sosial dengan perkembangan moral. Hal ini dibuktikan dengan koefisien korelasi $r_{x y}=0,362$ berarti $\mathrm{p}=0.000<0,050$, yang artinya semakin baik interaksi sosial maka semakin baik perkembangan moral remaja, sebaliknya semakin buruk interaksi sosial maka semakin buruk perkembangan moral remaja. Dengan demikian maka, hipotesis didalam penelitian ini diterima.

Interaksi sosial memberikan pengaruh $13,1 \%$ terhadap perkembangan moral. Masih terdapat $86,9 \%$ pengaruh dari faktor lain seperti mempelajari apa yang diharapkan kelompok, hati nurani, perasaan bersalah, dan pribadi anak dimana faktor tersebut dalam penelitian ini tidak dilihat.

Pada siswa SMA UISU Medan memiliki interaksi sosial dengan perkembangan moral yang baik. Sebab interaksi sosial dapat dilihat nilai empiriknya 117.772 lebih besar dari pada nilai rata-rata hipotetiknya, yakni 90 . Demikian pula halnya dengan perkembangan moral, nilai empirik 44.035 lebih kecil dari pada nilai rata-rata yakni 26.

\section{Saran}

Sejalan dengan hasil penelitian serta kesimpulan yang telah dibuat, maka halhal yang dapat disarankan adalah sebagai berikut : Orang tua dan guru diharapkan mampu lebih meningkatkan gambaran moral yang berhubungan dengan interaksi sosial terhadap anak sehingga dapat membentuk moral yang baik pada anak. Orang tua tetap memperhatikan kebutuhan-kebutuhan anak di tengah kesibukannya dan orang tua meluangkan waktunya untuk bercerita dengan anak mengenai masalah yang sedang dihadapi anak.

Subjek diharapkan dapat memperbaiki moral dalam dirinya karena buruknya moral dapat menyebabkan remaja bertindak kriminal, melukai dirinya sendiri, dan orang lain. 
Memperbaiki moral dengan cara meningkatkan interaksi dengan orang tua, dan lebih bersifat terbuka terhadap orang tua dalam hal apapun dan berani dalam mengungkapkan pendapat.

Menyadari bahwa penelitian ini masih memiliki berbagai kekurangan, maka disarankan kepada peneliti selanjutnya yang ingin melanjutkan penelitian yang sejenis untuk mengontrol faktor-faktor lain yang diperkirakan mempengaruhi perkembangan moral.

\section{DAFTAR PUSTAKA}

Ali, Moh dan Asrori, Moh (2004). Psikologi Remaja. Jakarta: Bumi Aksara.

dan Asori, M. (2005). Psikologi Perkembangan Remaja Peserta Didik. Jakarta: Bumi Aksara .

Daradjat, Z, (1996), Ilmu Jiwa Agama, Jakarta: Pt.Bulan Bintang

Dariyo, A. (2004). Psikologi Perkembangan Remaja. Bogor: Ghalia Indonesia.

Desmita. (2005). Psikologi Perkembangan. Bandung : Rosda.

Gunarsa, S. (1991).Psikologi Untuk Membimbing. Jakarta; PT.Rineka Cipta

, S, D \& Gunarsa, Y. (1995). Psikologi Praktis : Anak, Remaja dan Keluarga. Jakarta : PT. BPK Gunung Mulia.

Gerungan, W. A. (2004). Psikologi Sosial. Bandung: PT.Eresco.
Herimanto, Drs. (2008). Ilmu Sosial \& Budaya Dasar. Jakarta: Bumi Aksara

Hurlock, (1999). Psikologi Perkembangan. Jakarta: Erlangga -(1999). Psikologi

Perkembangan. Jakarta: Erlangga

Huky, W. (1986). Pengantar Sosiologi.Surabaya: Usaha Nasional

Idrus, M. (2009). Pengaruh Penelitian Ilmu Sosial. Yogyakarta: Erlangga

Santosa, (1992). Pengantar Psikologi Sosial. Cetakan II. Bandung: Eresco

Santosa, Slamet. (2004). Dinamika Kelompok. Jakarta :Bumi Aksara

Santrock, J. W. (2003). Adolesence :Perkembangan Remaja.Edisi Keenam.Jakarta: Erlangga.

(2005). Perkembangan Remaja. Jakarta: Erlangga.

Sarwono, S.W. (2010). Psikologi Remaja.Jakarta: Rajawali Press

Sobur, Alex, Drs. (2005). Psikologi Umum. Bandung: Pustaka Setia.

Sitorus, M. (1995). Sosiologi.Jakarta: Erlangga

Soekanto, Soerjono. (2012).Sosiologi Suatu Pengantar. Jakarta: Rajawali Pers.

Wahyuning W, Jash, Rachmadiana M.H. (2003). Mengkomunikasikan Moral Kepada Anak, Jakarta: PT. Elex Media Komputindo 